Technical and Bibllogrephic Notes / Notes techniques et bibliographiques

The Institute hes attampted to obtain the best orlpinal copy ovailable for filming. Features of this copy whlch moy be bibliographically unique, which $m w y$ olter any of the Images in tha reproduction, of which may signifieantly change tha usuel method of filming, ors checked balow.

7 Coloured covers/

Co' verture de couleur

Covers damand/

Couverture endommante

Covers restored and/or Ieminatad/

Couverture restourise et/ou pelliculik

Cover tithe missing/

Le titre de couverture manque

Coloured maps/

Cartus ghonraphiques en coulour

Coloured ink (i.e. other then blus or bleck)/

Encre de coulsur (i.e. autre que blewe ou noire)

Coloured plotes and/or illustrations/

Planches et/ou illustrations en coulaur

Bound with other material/

Ralib avee d'outres documents

Tight binding may cause shadows or distortion along interior margin/

La raliura sarrite peut causer de l'ombra ou de la distorsion le long de le marge intírleure

Blank leaves addad during restoration may appear within tha taxt. Whenever possible, these have been omitted from filmingl

II se peut qua cartaines pages blanches ojoutles lors d'une restauration oppareissont dens la texte. mais, lorsque celo stait possible. ces pages n'ont pas àte filmóes.

Additional comments:/

Commentairas supplímentaires:
L'Institut e microfilme la meilleur axemplaire qu'il lui o dé possible de se procurer. Las ditails de cat exemplaira qui sont peut-tre uniques du point de vue bibliographique, qui peuvent modifies une imege reproduite, ou qul peuvent exiger un modiflestion dans la mithods normale de filmege sont indiqubs ci-dessous.

Coloured paces/

Pages de coulsur

Puges damerad/

Pages endommanies

Pages restored and/or laminated/

Pages restauries ot/ou pallicultes

Pages discoloured, stainad or foxed/

Pages discolortes, exchetifes ou piquies

Pages datached/

Pages détachites

Showthrough/

Transparence

Quality of print veries/

Qualite inçale de l'impression

Continuous pagination/

Pagination continue

Includes index (es)

Comprend un (des) index

Titbe on header taken from:/

La titre da l'en-tlte proviant:

Titta page of issua/

Page de titre de is livraison

Caption of issud

Titra de depart de la livraison

Masthead/

Gànérique (périodiques) da la livraison

This item is filmed at tha raduction ratio checked bolow/

Ce document est filmé ou taux de riduction indiqué ci-dessous.

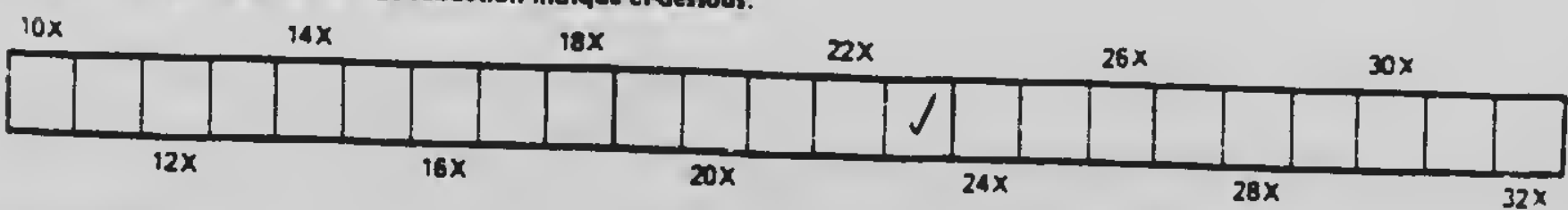


The copy flimed hare hes been reproduced thenks to the generosity of:

\section{Dougles Library \\ Queen's University}

The imeges eppeering here ore the best quellty possibie consldenng the condition ond Is: !lbility of the originel copy snd In keeping with the fliming contrect specificetions.

Origlnai coples in printed psper covers ere flimed beginning with the front cover end ending on the lest pege with 6 printed or Illustreted impresslon, or the beck cover when eppropriote. All othar origlnel coples sre fllmed boginning on the flrst pege with e printed or Illustroted Impresslon, end ending on the lest pegs with e printed or illustrated Impression.

The lest recorded frame on aech microfiche shall contaln the symbol - Imeaning "CONTINUED"), or the symbol $\nabla$ (meening "END"), whlchover opplies.

Maps, plates, cherts, etc., moy be flimed et diffarent reductlon ratlos. Those too ierge to be entireiy included in one exposure ere filmed beginning In the uppar loft hend corner, loft to right and top to bottom, es meny fremes es required. The following diegrems illustrate the mothod:
L'oxemploire filim fut reproduit orace géncrositó do:

$$
\begin{aligned}
& \text { Douglas Library } \\
& \text { Queon's University }
\end{aligned}
$$

Les Imoges sulventes ont dt reprodultes evec la plus grend soln, compte tenu de le condition ot ds is nottets ds l'exemplelre flims, ot en conformits ovec les conditlons du contret da filmege.

Les exempieires originoux dont le couverture an pepler sst Imprimbe sont filmos en commencent par lo premler piot st en terminent solt per la dernibre paga qui comporte une emprelnte d'Impreasion ou d'illustrotion, solt per lo second plot, selon le ces. Tous les eut se oxemploiras origineux sont filmbs en commencent per lo premlore pege qul comporte une emprsinte d'impression ou d'illustrotion ot en terminent par ia dernibre page qul comporte une telia emprointe.

Un des symboles sulvents eppereitre sur la derniore Image de cheque microfiche, selon la ces: le symbole - signifle "A SUIVRE", la symbole $\nabla$ slgnifla "FIN".

Les certes, plenches, tablooux, otc., peuvant etre flimbs das taux de róduction diffóronts. Loreque lo documant est trop grend pour etre reprodult on un soul clichs, il est filmo 8 partir de l'engie supśrleur geuche, de geuche drolte, et de heut en bes, en prenent le nombra d'imeges nócasselre. Les diegrammes sulvents Iliustrent ia mothode.
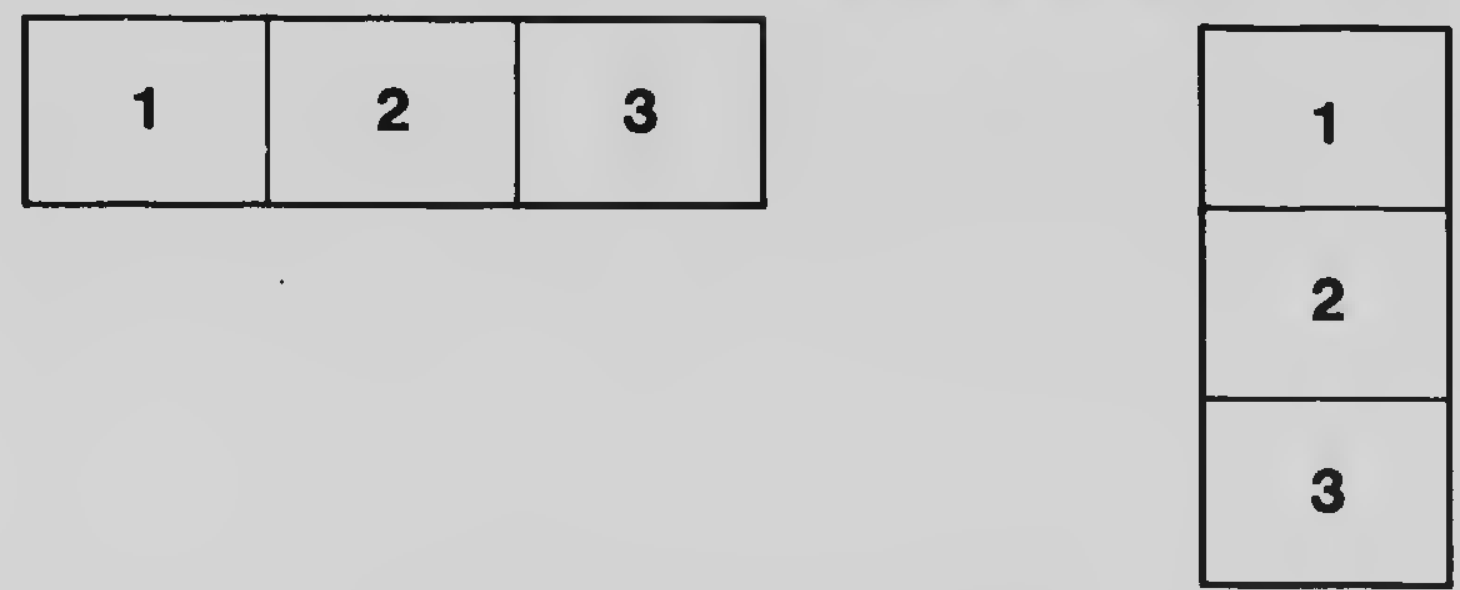

\begin{tabular}{|l|l|l|}
\hline 1 & 2 & 3 \\
\hline 4 & 5 & 6 \\
\hline
\end{tabular}




\section{MHCHOCONY RESOLUTION TEST CHART}

(ANSI and ISC TEST CHART No. 2)
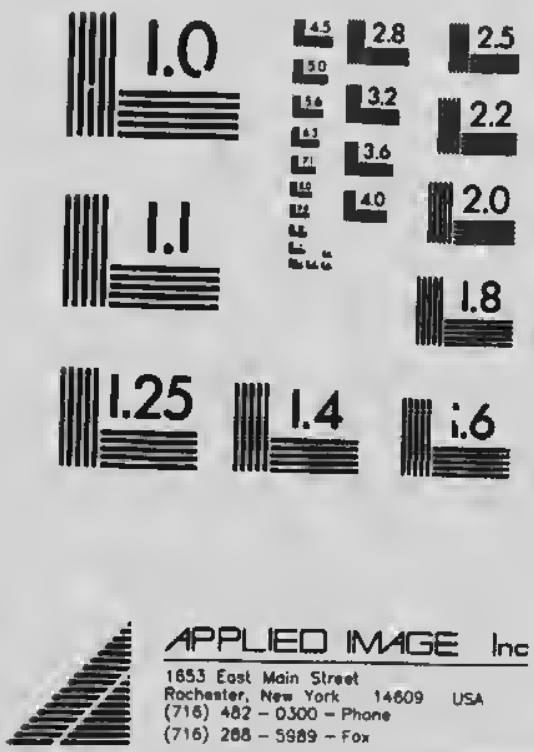


\section{The Quail}

The Best Insect and Weed Exterminator Must be Better Protected

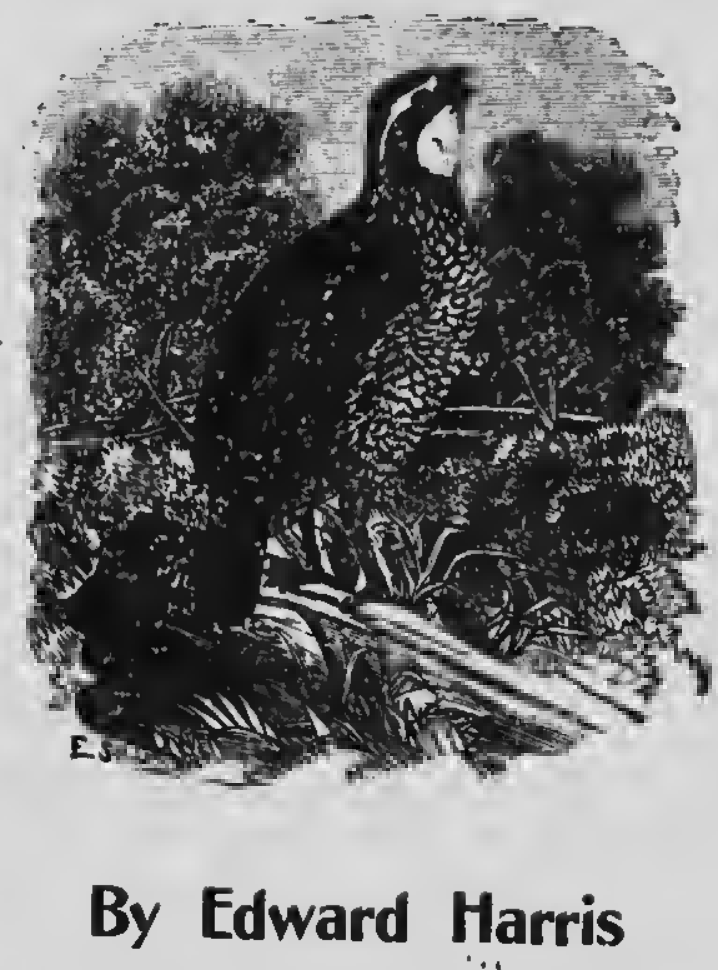

Price, 5 cents. For Sale by all Booksellers.

William Briggs, Publisher

Toronto 


\title{
The Quail
}

\section{THE BEST INSECT EXTERMINATOR}

\author{
$\cos$ \\ SHOULD BE PROTECTED FOR THE FARMER
}

202

PHE history of game legislation in Ontario has been somewhat peculiar - one might say, tragic. In the 50's quail had spread over the greater part of Western Ontario. In 1853 tho Great Western Railway was opened for traffic, and a demand for quail to supply the American, cities soon followed. This demand increased from year to year, with better prices for the birds. In 1854-55-56 Iondon was the centre of the quail belt, which then extended from the Detroit River to beyond Hamilton, to the Niggara Peninsula, and along tho Lake Erie shore. Norfolk was one of the best of the quaii counties. The farmer in those daye was comparatively a poor man. It is not a $r$ atter for surprise that when he found he could pay his taxes by trapping and netting quail in the barn yard in January and Fehruary, it soon became the custom of the country. At those dates netted quail were fed and kept in large coops for sale.

\section{Eportsmen Take action}

The first Act for the protection of quail was passed in 1856. For this Act we were indebted to the sportsmen of Ontario. Sportsmen were very prominent in obtaining all subsequent legislation. The results, as will be seen hereafter, were not entirely satisfactory. That there was always a strong influence against them is elear, for the exportation of quail was not prohibited until 1897. 
The Aet of 1856 protecterl quail from 1st Mareh to 1st Oetober. Tho trapping, notting antl export of quail increased to an extent to canse ulurn, nud in 1868 quail wero further protecterl by adding J Junury and February to tho close season. Those months were clearly the best for netting, barnyurd slunghter, and export.

\section{Jarmers 08. Sportsmen}

Competition has always been tho sonl of business. The rivalry between the farmers and thoir lroys, with their nets and trape, and the town and eity sports with their "two-burrel guns and sinell dogs," became so keen and disastrous that in 1871 quail wero fully protected for three years. That Aet was repealed tho following year, except in tho conntios of Essex, Kent, Lambton unl Middlesex. In 1877 quail had inereased in numbers, and were permitted to be shot. In 1886 quail were again fullv protected for the years 1886-87, hit in 1887 wo were legislated hack to the old dates. In 1890 the sale of quail was prohibited.

\section{Protected at Migbt and on Sunoay}

In 1892 shooting was prohibited betwoen sunset and sunrise, and on the Lord's Day. $\Lambda$ ttendance at church was provided for, as well as a quiet night's rest. The sale of quail was also prohibited for two years. In 1893 exposuro for sale was limited to five days. In 1897 we were once more legislated back to the old dates, and export prohibited. In 1899 quail wore permitted to be sold during tho hunting season and five days after. At this date, the shooting was almost wholly in the hands of the market-shooter. In 1900 we were again legislated back to the old dates. In 1002 quail were permitted to be shot in the month of November only.

\section{"Battue" Hert Jall}

There has been no legislation since, probably because quail had so nearly reachod extinction point that city, town and village sportsmen ceased to take any interest in the matter. 
lint in 190:3 we find in the Gamo Commisaion report a propusition to establish " puail hateleries." Ant, finully, in 1901. lyy order-in-Comeil, no quail are w he shot un 'il 1st Novemlerr, 1505. At that dute thewe is to be a grand attuo" and the quail finally exterminated, mules ce ixilleci oy tho promont Governinent.

This almost umpuralleled legislation, extrulling back nearly half a century, has practieally resulted in the extermination of guail. Tho reason is plain. All legishtion was inspired from the sane quarter, the intention being to kil] ruther than protect. With the advent of cheap brecel-loaling guus and fixed anmunit, m, quail were doomed. Tinoy beame a luxury for the rich, and the jot-hunter thrived.

Merehauts who had gins and eartricges to sell, took " conspicuons part in denomneing the destruetion of game, which eau only be compiared to Satuu reluking sin. Aul now all slich aro looking forward to the 1 st of Noveuber next for a graul "battue."

\section{Tbe first Ontarto Quatl}

Let us enquire what the quail is. It is not a bird of the forest, nor was it indigenous to this country. Genaral Simeoe, our first governor, never hearl of it. There were none iu the enuutry when he made his celebrated tonr with Col. 'ialbot, Givens and Littlelales. My mother, who was born in the connty of Norfolk one hundrel and five years ago, toll me she was about ten yeurs of age when flyc heard a bird whistle "Bob White" on the farm. She asked her father wat it wis. IIe said, "I am so glad-the claail lave enne." Il o was a hanished Loyalist from Now Jorsey, where the quail ware then in plenty.

'The Ontario quail crossel Iake Erie to the county of Fssex from Ohio, and to the enuty of Norfolk from Penusylvania. All eame from Mexico, following the settlements on the $\Lambda$ tlantic coast, beenming larger and hardier in tho eolder elimates. 


\section{a siro of the Jarm}

Mr. Edwin Sandys, in his work on game hirds, gives a very grood account of the quail:

"Prolific to an astoniabing degree, lie may be depended upon to hold his own under any reasonable conditions. Hardy and strong, he thrive under conditions which fow other hirds ean endure. His limited wanderings seldom take tho original brood from their native farm unless huntel. The quail is truly a bird of the farm, and tho eanu, follower of tho strong army of agriculture, attracted by the droppings of grain and seods, and tho insacts which follow tho cultivation of fruit, grain and vegetables."

\section{Tbe Grain and Jruit selt}

As the grain and fruit belt of Ontario hroadened, so did the renge of quail extend. $\mathrm{H}_{\theta}$ is content to watch for those lost grains which fall to hin by right. A sworn foe to the foes of the farm, lic hunts around the crowding stents for skulking insects, and what ho and his swarming tribe fail to detect can work but little harm. The seeds of somo of the most troublesolne weeds are his fuvorite food.

Quails' stonachs have been found filled with ants and larvæ, grasshoppers, erickets, the cut worm, caterpillars, weevils, locusts, potato and other beetles, cabbago worms, turnip $6 y$, wheat worıns and midges, and many inseots a torture tc live stock-in fact, nearly every insect a farmer is glad to get rid of. A young quail will consume its own weight in insects every day. This is the reason why they cannot be successfully raised in captivity.

Insects pass through four stages, the eggs, the larræ, the chrysalis, and the perfect insect. The hirds, which are wholly insectivorous, and come north during the sunmer months to breed, destroy the perfect insect. During the autumn, winter and spring quail depend largely for food upon the eggs, larvæ and chrysalis, as well as the perfect insect, and as insect destroyers are far more effeetive than the migratory insec-
tivorous birds." 


\section{a Bepp to a sarm}

Quail nover overeriwd a famn; thoy go in bevies, and a now hevy secks all adjoining furn, and so they spread over the wholo of our cultivated fields. Orehnrds aro favorite feeding grounds, but thoy never injure fruit, large or small. Quail are mostly monoganous, like uen, ouly occasionally imlygaInous. The fomalo hatches from thirten to fifteen egg-tho sparrow, only five, and we kıow how that hirl ineroases. Tho quail, if left undisturbed, will repeat her neating twiee, and seeasionally three times, iı a season. Any who are old enough to renember the alunst miraculous inereaso of quail in Ontario up to tho 60 's will realily believe this.

\section{Followed tbe Faracites}

The antiquity of tho quail entitles tho hird to sonı respect. Tho Israelites wore forty years in reaching the promised land after their exodus fro-1 Figyt. On that God-inspired journey they supported themselves and their families, which became a mighty host, hy enltivating the fields as they went from point to point. Wo have it in tho Bihlo thai quail followed them. The quail, in fact, is almost as much the companion of man as the dog, and belongs, hy right of cultivation of tho fields, to the farmer. The quail came up with the crop.

\section{An Interesting $\mathbf{3 i r o}$}

There is much to interest the atudent in the habits of this hird and his general make-up. He is absolutely fearless during the love-mating season, and will act as husband to the widow of a defunct male, and assist in bringing up her family.

Althongh a delicious morsel as an occasional luxury, he eannot be eate.l for any length of time without serious consequences to the consumer. This trait, if its consumption were localized, would be some protection for the hird, but the demand for it has been nnlimited in all eities reached by rail. Unlike tho domestic fowl, tho quail is self-smpporting and finds his own shelter. The female does not make her nest until May, when all danger froin cold and wet has passed, In suit- 
able runs, prepared for thein, the birds will hread and prove most interesting pets. Towarls the latter part of September the earlier broods become restless. This eontiunes and hecomes nore pronouneed, until it almost assumes the natire of a partial migration.

They then drift from place to placo and aro very unsettled, evidently an inherited wandering habit. It is this hahit which makes the rearing of quail by elnbs and enthusiastic individuals for sporting purposes a failuro. It is a bird of tho country, which must be free to eome and go, and if properly protected wonld spread over the greater part of Ontario. The quail belt is by no means confined to Essex and Kent. The Canuda quail was, the hardiest and finest specimen of the species; in all respects a survizal of the fittest; the Florida quail are not half tleir size and weight.

\section{Beneral Drotection Heeded}

If the quail are to be saved to us protection must now become general. hy the united aetion of the agrieulturists and the fruit growers. The question has hitherto been legislated upon and discussed from a sportsman's and epicure's point of view. It must now be considered from an insectivorous standpoint. The time for action is opportune. The sportsman eannot complain, as there are no longer sufficient birds to shoot to make the game worth the eandle; unless, indeed, an rrderin-Council prepares a "battue" for him. The epieure need not object, for he cannot get his "quail on toast" for love or money.

Nino hundred and ninety-nine men out of a thousand in Ontario have never tasted a quail; the number of people who have shot them for sport wonld probahly be less. After fifty. rears' legislation, beginning when quail were in abnndance. and ending when we had but a few scattered beries left. it is now suggested to establish a hatehery. The farms and lands whicl the industry of onr people have cultivated are the only possible hateheries. 


\section{foes of the Quall}

In Ontario man gave the quail no rest; the hird was hunted spring and fall, sumuler and winter, norning, nooll and night. Next to mant, the deadliest foes of the quail are crusted snew, extreme coll. liawks, and denestic cats. It, is salid that a quail with a full erop never freezes. There is truth in it. It applies to more than quail. J)iven, latlf-starverl, from their natural shelter. hounded by dogs and sportsmen, trapped, netted, and slowt in the harnyards, the quail are crecusionally cevered hy erusted snow and perisli. We lad the same climate in the 60 's, lut the rpisil had inereased, and were increasing ahundantly, and womld again if properly protected.

Two hawks only attack quail, Cooper's hawk and the sharpshinned hawk; as they destroy chickens also. the boys shoot them. The eat which destroys quail is ne lenger a domestic cat, but " a ranger," destroving any bird as it leaves the nest. The nsefulness of such a cat is gone.

\section{Jarmers Must Baclis the Lawg}

Man, the real destroyer of quail. ean he fettered hy legislation, but we have seen how valucless legislation is unless the farmers and cultivators of the soil make up their minds that quail were intended for greater things than sport and talle luxury. It is, indeed, a striking eontrast whell we regard Great Britain, with a limited miral area and a dense population. alounding in game and utaking indigenous the valuabls game lirds of other coulutries, while in Outario, witl a great rural area, we have inen cieprivel even of that supply which nature gave us, a free gift.

\section{Engligb Game Laws}

In England, where the franchise very nearly appronehes miversal suffrage, 11, ohjection is ever taken to those laws which make it possible to pretert birks. Similar laws wonld l.e in every way acceptahle in Ontario. There is in Enylund a fixed fine of $\$ 25$ for the vurious trespanses, and increased 
penalties for second offences. Tbe question of damage done is not left to the magistrate, as in Ontario. Verbal or written lotice can also be given not to trespass. Quail are more easily protected than any other bird. They do not frequent the woods unless driven there from enclosures and the cultivated fields. If farmers and their boys could be persuaded to become their triends they would always be in sight.

The wild turkey was the most timid and wildest of all Ameriean birds. Taken to Europe by Columbus and bred in eaptivity, the young birds were fed and petted till they became lamer than the ordinary barn-door fowl.

All our turkeys are descended from the native wild turkey. Tet an effort now be made to see what kindness may do for that most persecuted of all birds, the quail! .

\section{Damage Done by Sportsmen}

Mand farmers complain of injury to their eattle from irrespunsible shooting parties. That pernicions habit of breaking down fences and rambling over ficlds without the consent of the owner wonld he ehecked, were it even known that the ahove or similar provisions existed as part of the law of the land. Tawbreakers are rery tow in number; the great mass of the people obey the law. Some such effective legislation would be a boon to farmers in many tramp-inflicted localities, quite apart from the question of game protection.

\section{Quail (Dust thot be Disturbeo}

The preservation and restoration of quail and game dopends largely upon the existence of laws which, if enforced, would make sure the privacy and freedom from intrusion of property where game is. Man does so much to destroy quail and game, and so little to protect those birds, that it is reasonable provision ehould be made to leave them undisturbed, inore partieularly fluring the nesting season. A quail nest nnce disturbed, the female never returns to it. If is built upon the ground in the open, eultivated fields, and still very difficult to find. The dull plumage giren to the females of birds was intended to aid in their concealment when nesting. 


\section{Quail as 3nsect Đestroyers}

The professor in agriculture, probably disciplined by timid legislators, cannot be said to have grasped this question fearlessly. He has, as a rule, left qnail and game birds, as insect destroyers, severely alone. The expression, "Oh, give the boys a chance?" has sent many a man to Parliament and destroyed many an orchard and garden. It does not add to one's popularity to be "up against" the sports, who can flood tbe newspapers with emanations from their fertile brains, so in asking the "professor" for a fish he has given us a stone. That stone is poison and spraying. Spraying has now become an agricultural and horticultural household word. But spraying takes time and money and there is a growing feeling that it is not an unqualified success as a substitute for nature's own plan. Birds not only cost us nothing, but many of them are valuable weed destroyers, as well as insect destroyers.

\section{Faving the Orange Groves}

Every insect has its parasite; these parasites are usually hamnless. All perish by spraying. In California a few years ago the orange groves were being destroyed by a scale insect. After all efforts to exterminate it by spraying had failed, "lady bugs" were imported. In a very short time the scale liad disappeared, the orange groves wcre saved. The lady bug feeds upon the eggs of all insects.

\section{Sanctifying the Biros}

In Ontario every year smaller and more dreaded insects make their appearance, the parasites to keep them in check having been destroyed by spraying. In many cases the new insects are so diminutive that the microscope must be used to detect them; eren the San Jose seale is now a "back number." It reminds one of the nursery rlyme:

"Those larger fleas have smaller fleas

Upon their :ks to bite them;

Those smaller fleas have other fleas

And so on-ad infinitum!" 
Birds have played no mean part in shaping eivilization. Wo are largely indebted to prieste, and more particularly lieathen prieste, for saving us many of onr most valuahle birds. Their plan was to sannetify them. In India many valuable lirds liave been made aacred by the Hindus and Mahometans. In Prescott's "History of the Conquest of Mexico," there is a full description, as given by Cortez, of the ineredible number of quail there (A.D. 1520). The bird had been sanetified by the Aztecs, and was a delietey reserverl for priests only.

In most conntries it is considered unlieky to destroy swallows. In ancient Greece they were declared sacred. The Rhoodians had a hymu to the swallow, sung by the priests. It was also belicred whoever stole a swallow's egg would suffer some calmity, and so they protected their insectivorous birds.

\section{Tho Quail in Europe}

The quail is not known in England, Ireland or Scotland, nor in any of those European countries whence we eome. The value of the birl in agrienlturo has not been known. $\Lambda$ general enlightenunent is now required. Ignorance is not bliss in this connection.

A pamphlet, ealled "Canada," issued at Ottawa by anthority during the great Colonial Exhibition, 1886 (page 148), has the following: "Game liene is common property, and the hunter can find pecuniary profit in its pursuit."

T'his unwise and exaggerated statement sent us a temporary influx of "remittance men," with dogs and guns, but wholly unsuited for farm life, and in inany ways otherwise objectionable.

\section{A Breat bome Question}

It is not proluble that we shall be able to sanetify the bird, lut there are gool reasoiss why our elergy of all denominations slonld assist in forming public opinion to save us not only quail, lint all onr insectivorous birls. It is no longer a sporting questic, but a great and vital home question. No woodpecker escapes the cmall boy's catapult, a dead oriole, 
worth fifty cents, is an irresistible investment; meadow larks with their heads off are sold as quail. These may sound like trifles, hut in reality it means continuous and widespread slaughter. A city well policed knows nothing about this, but in small towns and villages there can be no check except "moral suasion." The children should be enlightencd on this suhject in the schools, and the teachers fully instructed how to impress children with the beauties and value of bird life.

\section{Tbe Curse of Insects}

Neither farmer nor fruit grower should permit a quail or any insectivorous hirds to be shot upon their premises for many years to come. It is now well known and undisputed that the loss to Canada through destructive insects runs into inillions of dollars yearly. The cry of "Back to the land" might indeed be a success were pe icious insect life once checked.

In any ordinary vegetahle and fruit garden there is now an, insect in everything except salsify. Even asparagus, the oldest known vegetable in the world, has its beotle, and escaping elsewhere, is for the first time attacked on this side of the Itlantic.

Edward Harris. 


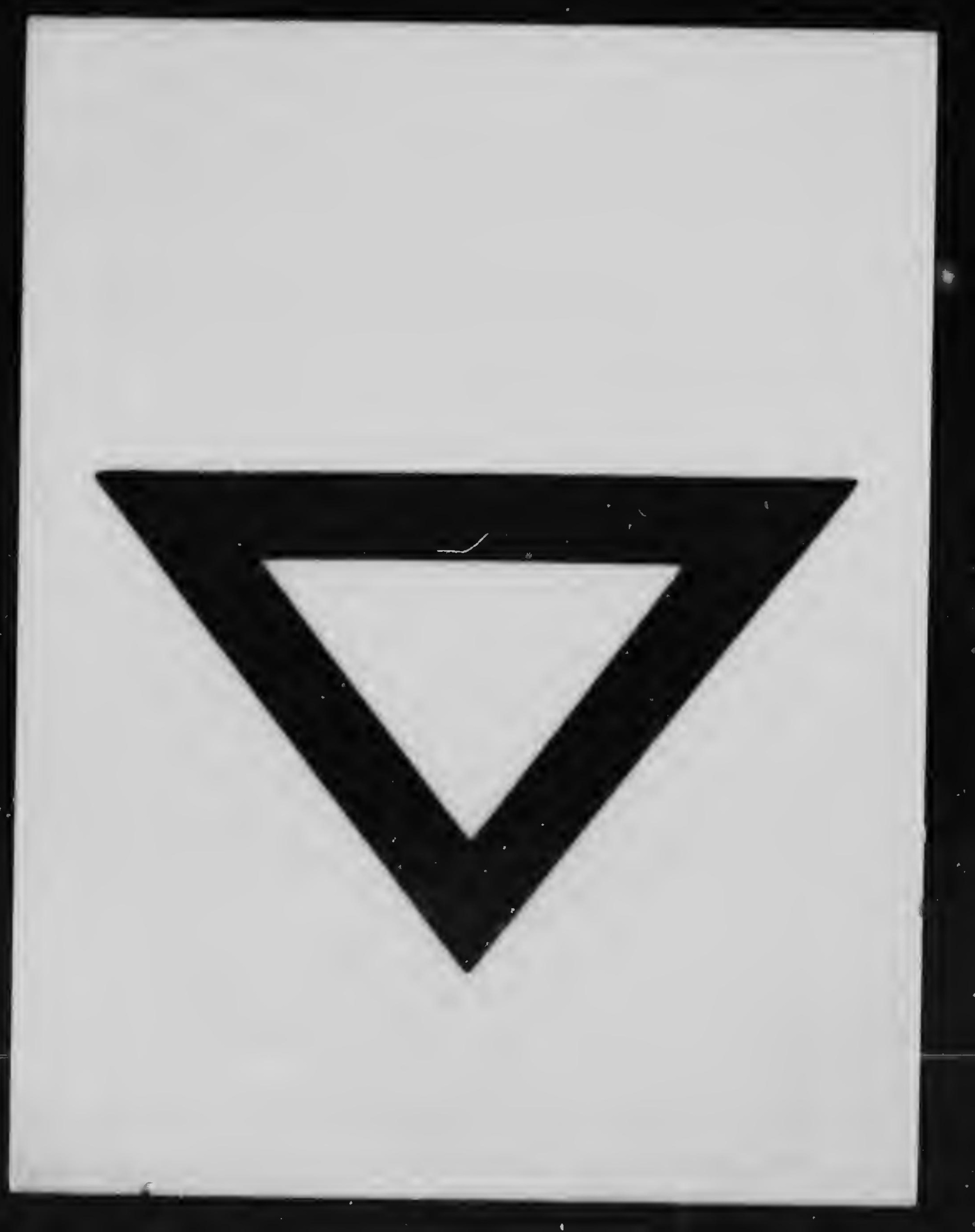

